\title{
Cyanobacteria of the thermal spring at Pancharevo, Sofia, Bulgaria
}

\author{
Jaromír LukavskÝ*1 ${ }^{*}$, Sevdalina Furnadzhieva ${ }^{2}$, Plamen Pilarski ${ }^{2}$ \\ ${ }^{1}$ Academy of Sciences of the Czech Republic, Institute of Botany, Department of Plant \\ Ecology, Centre for Bioindication and Revitalisation, Dukelská 135, CZ-37982 \\ Třeboň, the Czech Republic \\ ${ }^{2}$ Academy of Sciences of Bulgaria, Institute of Plant Physiology and Genetics, \\ Academician Bontschev Street 21, 3311 Sofia, Bulgaria
}

\begin{abstract}
Eight taxa of cyanobacteria were identified in the thermal spring at Pancharevo (in the Sofia basin, Bulgaria). As well as the widespread Lyngbya thermalis, Phormidesmis molle (syn. Phormidium molle), Phormidium papyraceum, Phormidium corium and Mastigocladus laminosus, four species were identified for the first time in Bulgaria: Calothrix thermalis, Gloeocapsa gelatinosa, Leibleinia epiphytica and Symploca thermalis.
\end{abstract}

Key words: Bulgaria, cyanobacteria, Pancharevo, thermal spring

\section{Introduction}

Thermophilic cyanobacteria are interesting study organisms for basic as well as for applied research. Their ancestors are possibly the oldest primary producer organisms common in the distant past, and they perhaps used thermal springs as refugia (GoLD 1992, 1999; Plescia et al. 2001; AdHIKARY 2006; IZAgIURRE et al. 2006; HindÁK 2008). MiLLER et al. (2006, 2007) have recently compared 37 strains of Mastigocladus laminosus isolated from sites throughout the world, analyzed 839 nucleotides of the 16S rRNA gene, and reconstructed phylogenies for the nitrogen metabolism genes. They concluded that, although the species per se is cosmopolitan, its populations are genetically differentiated on local geographic scales and genetically isolated by distance. A common ancestor may have been located in the Yellowstone area (USA).

Hexadecenoic acids have a possibly important role in the adaptation of Cyanobacteria to high temperatures and the ratio between saturated and unsaturated fatty acids (S/U ratio) decreases with decreasing temperature of a thermophilic strain of Synechococcus (MASLOVA et al. 2004). In mesophilic strains cultivated at $25-32{ }^{\circ} \mathrm{C}$ the $\mathrm{S} / \mathrm{U}$ ratio was increased. A change in the $\mathrm{S} / \mathrm{U}$ ratio, the mechanism of adaptation of algae to high temperatures, was

* Corresponding author, e-mail: lukavsky@botany.cas.cz

Copyright $^{\circledR} 2011$ by Acta Botanica Croatica, the Faculty of Science, University of Zagreb. All rights reserved. 
documented from a quite opposite spectrum of conditions. Cryoseston species of Chloromonas, isolated from Antarctica, had a higher proportion of unsaturated acids, enabling the functioning of cells in temperatures just above zero (BIDIGARE et al. 1993).

Thermal springs represent pools of new strains possessing attractive biochemical pathways and unusual metabolic products for biotechnological applications. For example, the thermotolerant Phormidium sp. produced an anti-microbial material against $\mathrm{G}^{-}, \mathrm{G}^{+}$bacteria, Candida albicans and Cladosporidium resinae (FISH and CoDD 1994). Another Phormidium sp., immobilized in calcium alginate, was used for treatment of dye-rich wastewater, (ERTUGRUL et al. 2007). Cancer drugs were produced from thermophilic cyanobacteria by JAVOR (1999). Some unusual Fe-proteins, siderophores, were identified in some thermophiles ( ̌̌EZANKA and LUKAVSKÝ, not published). Ferredioxins from Mastigocladus laminosus, however, act as toxins and restrict public use exploitation of a spring in Saudi Arabia (Mohamed 2008). Thermophilic Synechococcus sp. is a potential producer of poly$-\beta$-hydroxybutyrate, which is the basis of biologically degradable plastics (MIYAKE et al. 1996). Production of hydrogen by some cyanobacteria is a promising source of energy for the future (MiTsui 1987). The exploitation of natural hot water with a large content of $\mathrm{CO}_{2}$ is highly profitable for algal biotechnology, e.g. production of Spirulina (FouRNADZHIEVA et al. 2002) and potentially for production of thermal species. Precipitation of travertine, using cultures of thermal cyanobacteria, is a promising method for capturing and sinking $\mathrm{CO}_{2}$ of anthropogenic origin (HAYASHI et al. 1994, ONO and CuELlo 2007). Thermophilic cyanobacteria also have the potential to remove nutrients from thermal effluents (WEISMANN et al. 1998). Cultivation of thermophilic algae is easy, due to the rapid growth and resistance to common »weedy« species, under extreme temperature.

In Bulgaria there are more than 850 thermal springs and boreholes (PENTCHEVA et al. 1997). They have been exploited since antiquity; the majority of springs were in semi-natural conditions and populated with cyanobacteria and algae. Presently, many of the springs are being exploited (captured belowground), and thus the original algal flora is disappearing.

In the period, 1898-2001, over 200 taxa of algae and cyanobacteria comprising 67 genera were identified from hot springs in Bulgaria (STOYNEVA 2003). In algal flora of Bulgaria, VodENICHAROV et al. (1971) listed 29 species of Cyanobacteria and 4 species of thermophilic Chlorophyta. Later, 26 genera (75 taxa) of Chlorophyta were identified in thermal springs and published, together with a comprehensive review of historical data and literature (STOYNEVA 2003, STOYNEVA and GÄRTNER 2004). Recently, 26 springs were investigated in the Sofia and Sandanski basins (FurNADZHIEVA et al. 2006). The Sofia basin is famous for mineral hot springs, five of them are generally known, three are of the nitrogen type, two of $\mathrm{CO}_{2}$ type (PENTCHEVA et al. 1997).

The aims of our project were to contribute to the check-list of Bulgarian flora and to identify and isolate strains promising for biotechnology. All organisms were carefully documented, including their morphological variability, because of continuous changes in the taxonomy of Cyanobacteria.

\section{Material and methods}

\section{The study site}

The study site has been already characterized by PENTCHEVA et al. (1997). Measurement of temperature was focused on the actual value at the sampling site. Live samples were col- 
lected into Eppendorf tubes, of $2 \mathrm{ml}$ volumes, replicates were preserved with formaldehyde to a final concentration of $2 \%$. Live cells were inoculated into wells of immunological plates $(9 \times 13 \mathrm{~cm}$, with 96 wells a $0.25 \mathrm{~mL})$, filled with $0.1 \mathrm{~mL}$ per well of nutrient solution D after CASTENHOLZ (1969), solidified with $2 \%$ of agar, and sealed with Parafilm foil with a lid. Live samples were stored in the dark at room temperature during transport (CASTENHOLZ 1969). Minicultures in wells were later inoculated into E-flasks with liquid D medium and exposed to standard environmental conditions $\left(46{ }^{\circ} \mathrm{C}\right.$, irradiated by fluorescent tubes (day type, $\mathrm{PhAR}=30 \mathrm{~W} \cdot \mathrm{m}^{-2}$ ), $\mathrm{CO}_{2}$ was not added).

Pancharevo, region of Sofia, $\left(42^{\circ} 36^{\prime} 07.57^{\prime \prime} \mathrm{N}, 23^{\circ} 24^{\prime} 13.12^{\prime \prime} \mathrm{E}\right)$ spring is near a bath house. Type is dolomite + limestone, pipes with water $49.5^{\circ} \mathrm{C}, 10 \mathrm{~L} \mathrm{sec}^{-1}, \mathrm{pH} 7.3$, conductivity $84.7 \mu \mathrm{S} \mathrm{cm}^{-1}$, composition in $\mu \mathrm{g} \mathrm{L}^{-1}: \mathrm{O}_{2}-1.2, \mathrm{HCO}_{3}-315000, \mathrm{CO}_{3}{ }^{2-}-410, \mathrm{NO}_{2}-$ $20, \mathrm{NO}_{3}-2000, \mathrm{PO}_{4}{ }^{3-}-7, \mathrm{~K}-1860, \mathrm{Ca}-54300, \mathrm{HS}<50, \mathrm{~S}_{2} \mathrm{O}_{3}{ }^{2-}<300, \mathrm{SO}_{3}{ }^{2-}<210, \mathrm{SO}_{4}$ ${ }^{2-}-38500, \mathrm{Fe}-35$. Detailed data are available in PENTCHEVA et al. (1997). Outlet of water is open to the atmosphere and the flow is oscillating, is diverted into a reservoir, and is used for public laundry purposes (Plate 4, Fig. 3). Growth on concrete walls was green-blue to green-red, in different places (Plate 4, Fig. 2).

\section{Microscopic observations}

Microscopic observations were conducted with NU 2 and Amplival microscopes (Carl Zeiss, Jena) equipped with objective lens HI 100/1.3, and microphotographs were taken with an Olympus BX50, with HI 100/1.32 and equipped with a digital camera DP10.

\section{Determination}

Cyanobacteria were determined using monographs and keys of ANAGNOSTIDIS (1961), Starmach (1966), Anagnostidis and Komárek (1990), KomáreK and AnAgnostidis (1998, 2005), and other literature cited in References.

\section{Results and discussion}

We have determined eight taxa in the hot spring of Pancharevo (Plates 1-3, 5). The mats of the cyanobacteria differ according to their position with respect to the outlet of the hot water, i.e. splashing and temperature. The species marked with asterisk $\left(^{*}\right)$ are new records for Bulgaria, as compared to VoDENICHAROV et al. (1971).

*Gloeocapsa gelatinosa (Meneghini) Kützing 1843

Plate 1, Fig. 5; Plate 2, Figs. 8-11; Plate 5, Figs. 8, 17-19.

Description: Cells rounded, $3 \mu \mathrm{m}$ in diameter, daughter cells together in 2- more colonies in transparent, not laminated mucilage of a mother cell. Small granules scattered in cell, colour bright green-blue. Division of daughter cells in 3 perpendicular planes, colonies two-dimensional and grow up into a great irregular mass (Plate 2, Fig. 18). It grows as a black growth on the concrete walls of the spring (Plate 4, Fig. 4, arrow).

Notes: G. gelatinosa has been observed in central and south-east Europe, Israel, Africa, Asia and USA. Similar to Gloeocapsa gelatinosa LEMMERMANN 1905, with respect to morphology of colonies and also ecology, but the latter has smaller cells, only 1-1.6 $\mu \mathrm{m}$ in di- 

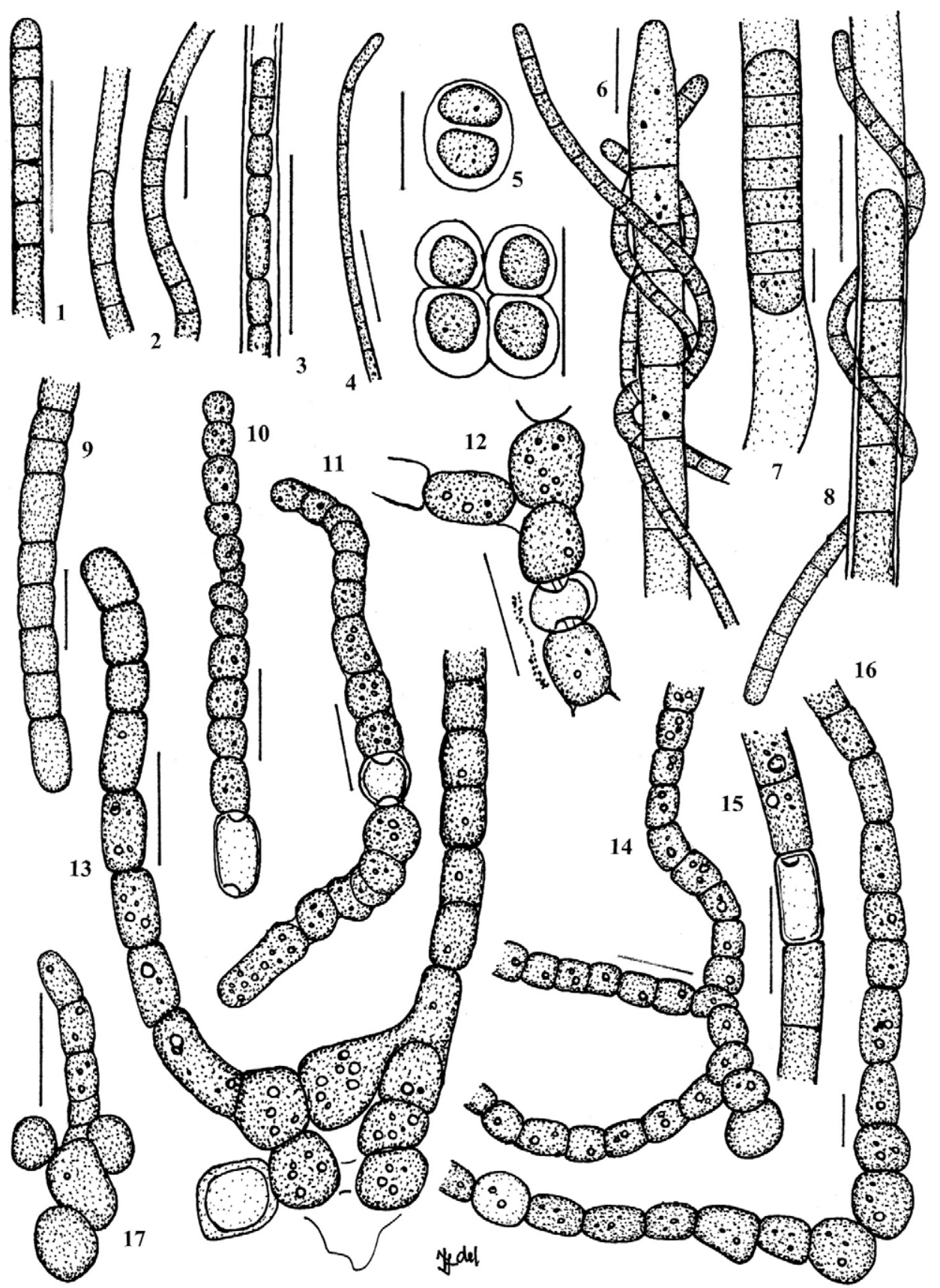

Plate 1. Cyanobacteria in thermal spring in Pancharevo, leg. 10.VII.2005 and 15.VII.2006. 1-3 Phormidesmis molle $\mathbf{4}$-Symploca thermalis. 5 - Gloeocapsa gelatinosa. 6, 8-Phormidium corrium, with epiphytic Lyngbya epiphytica. 7 - Phormidium papyraceum. 9-17 - Mastigocladus laminosus. 9 - lateral branch, 10, 11 - M.l. fa. oscillarioides, 12-14, 16, 17 - M.l. fa. typica. $15-$ M.l. with elongated heterocyte. Scale $=10 \mu \mathrm{m}$. 
ameter. It was described from Hawaii (hot spring near volcano, Mauna Kea), later recorded in the hot springs of Europe (Greece, France, Hungary) mainly as atmophytic (KoMÁREK and ANAGNOSTIDIS 1998). The alga was studied as a producer of capsular polysaccharides and a potential bioadsorber of $\mathrm{Pb}$ from waste (RAUNGSOMBOON et al. 2006). The black colour is for protection against UV irradiation (LEWIN 2006).

*Leibleinia epiphytica (Hieronymus) Compère 1985 (syn. Schizothrix calcicola (C. Agardh) Gomont, syn. Lyngbya epiphytica Hieronymus in Kirschner 1898. incl.) Plate 1, Figs. 6, 8.

Description: Cells $1.7 \times 5 \mu \mathrm{m}$, cylindrical, longer than wide, terminal cells rounded, content bright-blue, with very fine structure, sheath not visible. Filaments twisted around Phormidium corium, attached mainly by central part, both ends of filaments grow upwards.

Notes: Our species agrees with the description in morphology and size of cells, thin or invisible sheath. In the original description, whole filaments are attached by their entire length to host filaments. It has been recorded in freshwater, and also in thermal springs of lower temperature. In thermal springs, an epiphytic cyanobacterium was observed also in Yellowstone National Park, on Calothrix and described as Leibleinia calotrichicola (KoMÁREK and ANAGNOSTIDIS 2005).

*Phormidesmis molle (Gomont) Turichia et al. 2009 (syn. Phormidium molle Gomont 1892, Lyngbya mollis (Gomont) Compère 1974), was described by ANAGNOSTIDIS 1961 and TuricchiA et al. (2009). Plate 1, Figs. 1-3; Plate 2, Figs. 6, 12-16, 19-20, 23, 24.

Description: Cells cylindrical, barrel-shape, little or more constricted at terminal cells, $2-2.3 \times 3 \mu \mathrm{m}$, sheath fine, colourless. Terminal cells rounded to little conical, colour of protoplast green - green-red, dominate, with Lyngbya thermalis, on concrete walls.

Notes: Our species agrees with the morphological description and size of cells and sheath. It has been recorded occasionally in thermal springs in Europe, mostly on margins and walls (KomÁreK and ANAgnostidis 2005, KomÁrek et al. 2009). P. molle is a pantropical species; it occurs in waters with abundant water vegetation, growing in clusters and mats. Morphologically, it is very similar to Phormidesmis pristley (Fritsch) (TURICCHIA et al. 2009), which was collected from Antarctica, in rapidly streaming water, attached on stones as reddish-brown mats. The similarity of the clade of $P$. molle and $P$. pristley to typical Phormidium, is $91 \%$. The genus Phormidesmis is, however, based on the typical tropical type species of $P$. molle. The species was shown to produce bioactive substances such as microcystins and compounds with anti-tumor activities (TENEVA et al. 2005). The strain Lukavsky 2008/31 is deposited in the culture collection of CCALA Třeboň. Sp.n. for Bulgaria.

Phormidium corium Gomont 1892 (Lynbya corium (Agard) ex Hansgirg 1892, Lynbya paulistana Senna 1983, Phormidium corium f. woronichiana Elenkin 1949, Phormidium corium fa. sensu Anagnostidis 1961). Plate 1, Figs. 6, 8.

Description: Cells cylindrical, wide $4-4.5 \times 7-12 \mu \mathrm{m}$, contents of cells fine, dirty blue-green, terminal cells longer, rounded - little conical, sheath fine, can be empty at ends, filaments straight. On concrete walls splashed with hot water, subdominate with mixture with Symploca thermalis. 


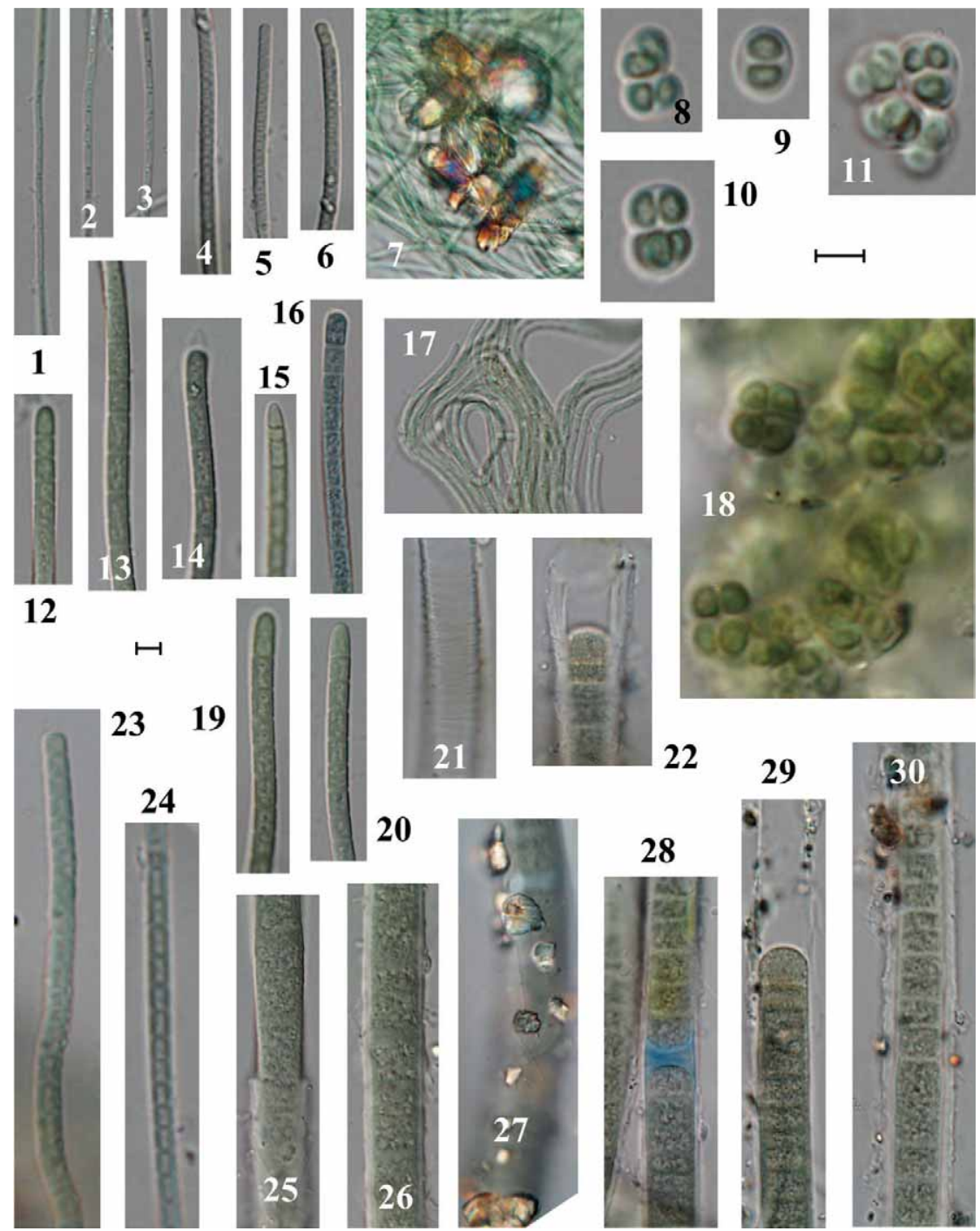

Plate 2. Cyanobacteria in Pancharevo, leg. 10 July 2005 and 15 July 2006. 1-3, 7, 17 - Symploca thermalis. 4-6, 12-16, 19-20, 23, 24 - Phormidesmis molle. 8-11, 18 - Gloeocapsa gelatinosa. 21, 22, 25-30 - Lyngbya thermalis. 7, 27, 30 - precipitation of travertine by cyanobacteria. Bars indicate $10 \mu \mathrm{m}$. Scale in right up is valid only for Figs. 8-11,18.

Notes: Our species agrees in morphology and size of cells, and also in little conical terminal cells. Nevertheless, after KOMÁREK and ANAGNOSTIDIS (2005), occurrence in thermal springs is problematic, including a record of $P$. corium sensu ANAGNOSTIDIS (1961). Nevertheless, the drawings of ANAGNOSTIDIs (1961, Tab. X, Figs. 59-60) are identical with our species. P. corium, which is recognised as a marine species (BHANDARI and SHARMA 2006, BHANDARI et al. 2007). It has been investigated with respect to photosynthesis, fatty acids, DNA, and its reaction to UV-B radiation. 

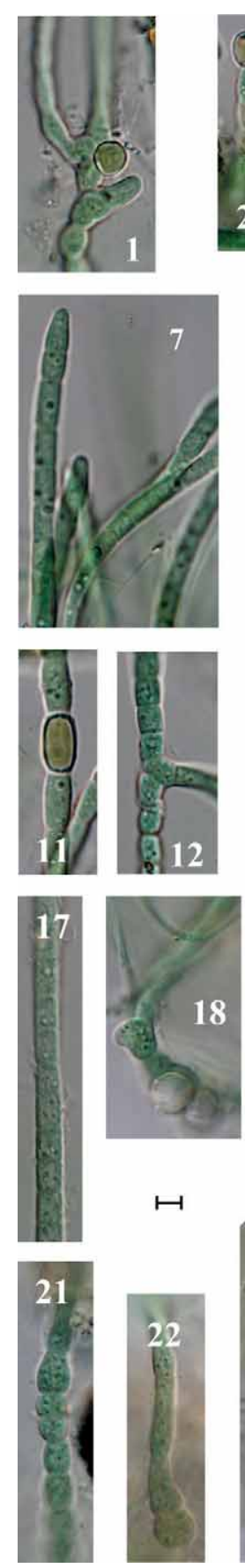
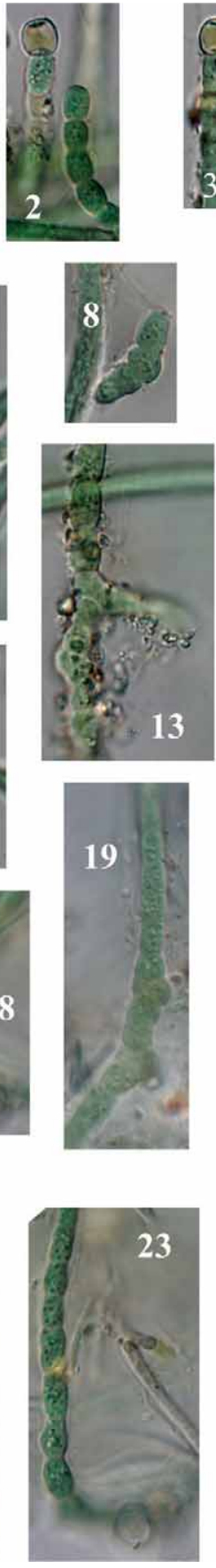
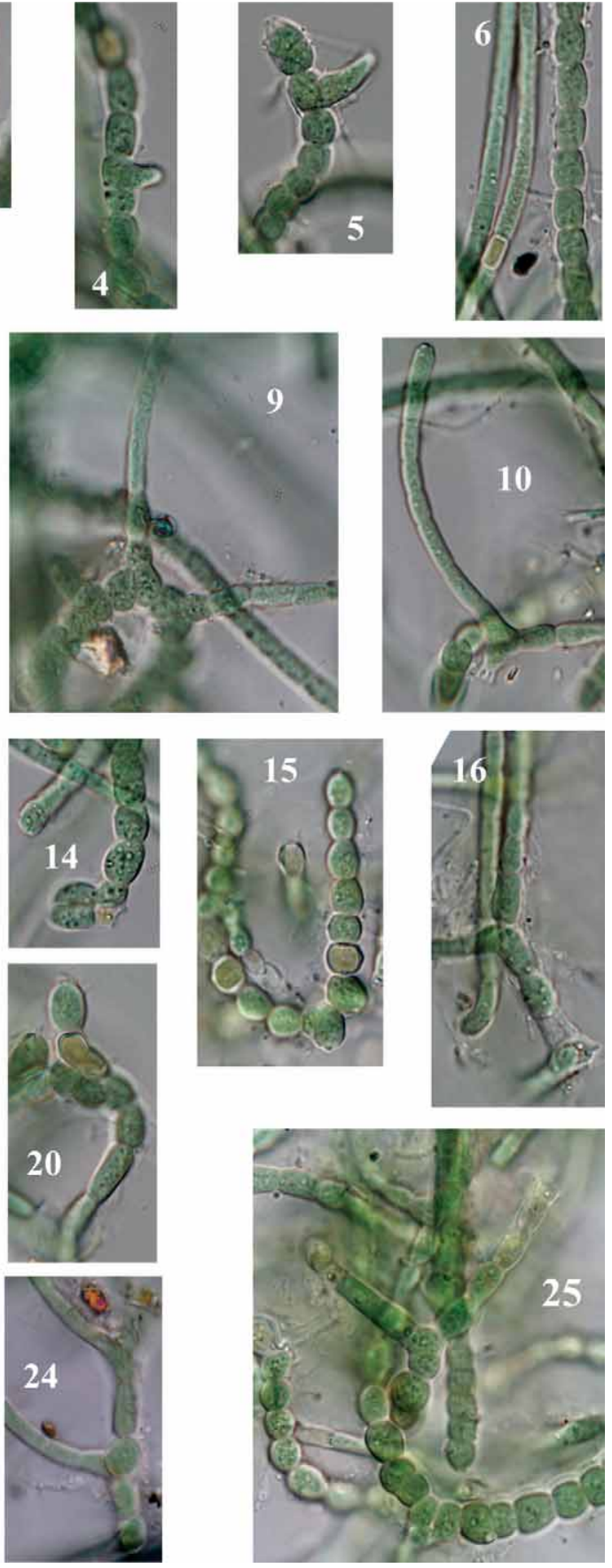

Plate 3. Morphological variability of Mastigocladus laminosus. Pancharevo, leg. 10 July 2005. 1, 5, 9, 10, 15, 16, 19, 21, 22, 23, 24, 25 - M.l. fa. typica. 6, 17 - M.l. fa. phormidioides. 2, 3-terminal heterocyte. 1, 6, 11, 20 - intercalary heterocytes. 14, 18 - rudimentary heterocytes. $\mathbf{7}$, 17 - lateral branches. 8 -hormogonium. Bar denotes $10 \mu \mathrm{m}$. 
*Symploca thermalis Gomont ex Gomont 1892

Plate 2, Figs. 1-3, 7, 17; Plate 5, Figs. 6, 7, 10, 21-22.

Description: Cells cylindrical, $0.8-1.5 \times 5-7 \mu \mathrm{m}$, slightly constricted by cross walls, green-blue colour, cell content fine with two distinct granules by both cross walls, filaments straight or little curved, in dense mats, sheaths hyaline, very fine or invisible, with no empty ends, terminal cells rounded not different from filament ones.

Notes: The species dominated in some samples, trichomes were joined in dense clusters, and precipitating crystals of calcium carbonate were inside (Plate 2, Fig. 7). It developed, together with Phormidium molle, a dense growth, coloured blue-green to green-red, on concrete walls. The trichomes are fine, cells $2-3 \times 7 \mu \mathrm{m}$ long, cell content fine with 2 granules at both poles of every cell, sheath fine or invisible. The species is known from hot springs all over Europe as well as Kamchatka Peninsula, Iceland, Israel, Algeria, Canada, USA, etc. It grows on walls and rocks up to $50{ }^{\circ} \mathrm{C}$. Symploca differs from Phormidium only by growth form in fascicles (KOMÁREK and ANAGNOSTIDIS 2005).

It is easy to cultivate and its biomass contains interesting siderophores, proteins including Fe (̌̌EZANKA and LuKAVSKÝ, not published). The strain Lukavsky 2008/29 is deposited in culture collection of CCALA Třeboň. Sp.nov. for Bulgaria.

Lyngbya thermalis Kützing ex Gomont 1892 (Lyngbya martensiana sensu ANAGNOSTIDIS 1961). Plate 2, Figs. 21, 22, 25-30; Plate 5, Figs. 1-5.

Description: Cells $11 \times 5-8 \mu \mathrm{m}$, inside cells fine and greater spheres, not constricted at poles terminal cells rounded, sheath fine, colourless, by aging become thick and lamellated, filaments later ca $15 \mu \mathrm{m}$ in diameter, with calcium carbonate crystals on surface. Necroidal cells brightly blue, they separate the filament into short parts, which move inside the sheath. It dominates in growth on walls, colour is blue-green to reddish.

Notes: Our species was morphologically identical with the drawing of PALIK (1949). ANAGNOSTIDIS (1961) has an identical organism and determined it as Lyngbya martensiana in his drawing (Tab. X., Fig. 53 $\alpha$ ). The species occurred on the margins of thermal springs of Europe (KOMÁREK and ANAGNOSTIDIS 2005). In the List of thermal algae of VODENICHAROV et al. (1971) it is listed as Lyngbya martensiana in Plovdiv and Tynsko.

*Calothrix thermalis (Schwabe) Hansgirg (Calothrix parietina f. thermalis G. S. West, Mastichonema thermale Schwabe). Plate 5, Figs. 11-16.

Description: Cells width $4 \mu \mathrm{m}$, filaments width $5 \mu \mathrm{m}$, including yellow coloured mucillage sheath, bearing heterocysts, basal, transparent. The end of filament rounded, width $3 \mu \mathrm{m}$, emerging from sheath.

Notes: $C$. thermalis, together with Gloeocapsa gelatinosa, dominated a yellow-red mat on the concrete wall. This species proved to produce the inhibitor of acetylcholinesterase, and is a potential drug for curing Alzheimer's disease (BECHER et al. 2009). It is a new species for Bulgaria.

Mastigocladus laminosus Cohn ex Kirschner 1898 Plate 1, Figs. 9-17; Plate 3, Figs. 1-25.

Description: Cells of basal filaments rounded, $3-8 \mu \mathrm{m}$ in diameter, branch cells cylindrical, $4 \times 8 \mu \mathrm{m}$, bright blue-green, distinct granules scattered in cytoplasm. Heterocytes 
colourless, rounded, $6 \mu \mathrm{m}$ diameter, rarely cylindrical $5 \times 8 \mu \mathrm{m}$, intercalar, rarely apical (Plate 3, Figs. 2, 3). Basal filaments are branched, reverse Y branching according ANAGNOSTIDIS and KomÁreK 1990, (Plate 1, Figs. 16; Plate 3, Fig. 15), saddle-shape (Plate 3, Fig. 9) or branches emerge upright from basal filament (Plate 3, Fig. 24).

Notes: Mastigocladus laminosus was described from Karlovy Vary (Bohemia) by CoHn (1862), later it was approved by KAŠTOvsKÝ (2001) and Kaštovský and Komárek (2001). It is considered in many textbooks as a typical thermal cyanobacteria, growing in temperatures $<60^{\circ} \mathrm{C}, \mathrm{pH}>7.5$ and low salinity. Its taxonomic position, however, is complicated, because of its extreme morphological variability. It has been described as having different morphotypes: status, or forma »anabaenoides, nostocoides, oscillarioides, tolypotrichoides, scytonematoides, plectonematoides, Chlorogloeopsis«, also as subforma »normalis, subrecta, spiroides « etc.

KAŠTOVSKÝ and JOHANSEN (2008) concluded that the name Mastigocladus laminosus should be reserved for populations with true branching filaments, growing only in thermal springs (f. laminosus). Their conclusions were based on comparison of the morphology of four of their own strains as well as comparison of analyses of 16S rRNA of 256 heterocytous cyanobacteria. M. laminosus f. nostocoides Frèmy is the second thermal taxon, but with unbranched filaments, and with life cycle steps morphologically similar to another taxon, M. laminosus f. oscillarioides Frèmy. It forms Nostocacean-like filaments, ensheated filaments, also filaments with Chlorogloeopsis-like branching, producing akinetes, heterocytes, and hormogonia.

Homogenity in DGGE banding profiles of the populations of a hot spring at Ranong, Thailand, proved that $16 \mathrm{~S}$ rDNA gene distributions change along the thermal gradient 40-60 ${ }^{\circ} \mathrm{C}$, regardless of seasons (UdOMLuK et al. 2006). Also, MiLler et al. (2009) found sympatric diversification along a temperature gradient $\left(39-54{ }^{\circ} \mathrm{C}\right)$ as a potent source of evolution, in White Creek, Yellowstone N.P. Geographic isolation may be an important aspect of cyanophycean evolution, including Mastigocladus, studied in Costa Rica, (FInSINGER et al. 2008).

Castenholz (1972) forecasted the existence of the two genetic types in Mastigocladus in his paper about Surtsey Island. They differ not only in morphology, but also in growth optima, since the branched form grew in $<53^{\circ} \mathrm{C}$, whereas the unbranched form grew in $60{ }^{\circ} \mathrm{C}$.

In our materials collected from other localities in Bulgaria, some of these forms were in coexistence, also with transient forms as well as together with the typical branched »fo. typica«. Characteristic colour, and granules in cytoplasma (Plate 1, Fig. 3) nevertheless, speak for an identical taxon.

The validity of a gap between Mastigocladus and unbranched Chlorogloeopsis (KoMÁREK and HAUER 2010) was proved also by 16S rRNA analysis (WILMOTTE et al. 1993); they also proposed that the ability to produce heterocytes can be lost by mutation. Also, Chlorogloeopsis fritschii is not so homogenous a species, since two different types of germination of akinetes were observed (HINDÁK 2008).

Heterocytes: Population of typical M. laminosus in Pancharevo generally has heterocytes and a content of Ntot was $0.7 \mathrm{mg} \mathrm{L}^{-1}$ (PentcheVA et al. 1997). This concurs with the results of MiLler et al. (2006), who reported that M. laminosus from White Creek (Ntot $<0.1 \mathrm{mg} \mathrm{L}^{-1}$ ) produced heterocytes, whereas M. laminosus in boiling water where nitrogen was more rich $\left(\mathrm{Ntot}=0.15 \mathrm{mg} \mathrm{L}^{-1}\right)$ did not. Also acetylene reduction activity fits with the 

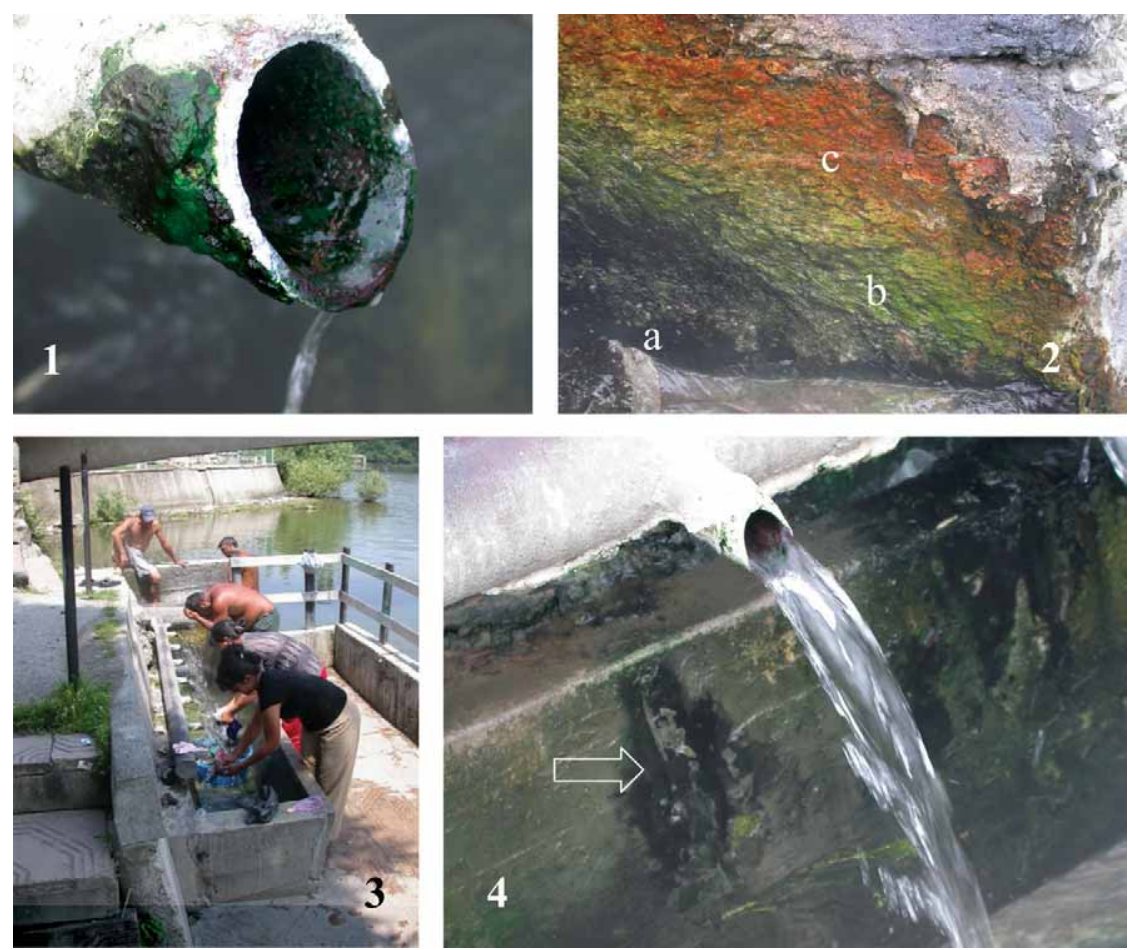

Plate 4. Thermal spring in Pancharevo, Sofia. 1 - Growth inside and on outer wall of the pipe, temperature of water was $48.5^{\circ} \mathrm{C}$, flowing periodically, dominated by Mastigocladus laminosus. 2 - Stratified growth on concrete wall, with respect to different temperature and splashing, $\mathbf{a}-43^{\circ} \mathrm{C}$, dominated by Lyngbya thermalis. $\mathbf{b}-21^{\circ} \mathrm{C}$, dominated by Symploca thermalis and Gloeocapsa gelatinosa. $\mathbf{c}-16^{\circ} \mathrm{C}$, dry, wetted only by vapour, was settled with Phormidium molle, Calothrix thermalis, Gloeocapsa gelatinosa and Symploca thermalis. 3 - The outlet of the thermal spring at Pancharevo is used as a public laundry. 4-Black growth on concrete wall by pipe, temperature $22^{\circ} \mathrm{C}$, dominated by Lyngbya thermalis and Phormidesmis molle.

presence of heterocytes for the White Creek population 151.5 and hot water culture $1.5 \mathrm{mg}$ $\mathrm{N} \mathrm{L}^{-1}$. Unfortunately, they are no available data about $\mathrm{N}$ content in springs on Surtsey Island (CASTENHOLZ p.c.), where heterocytes were also present. N-fixation, growth rate, pigment contents, etc. were compared in a group of 10 strains of Stigonematales, and $M$. laminosus proved to be not the best biomass producer, but a good $\mathrm{N}$-fixer (SINGH et al. 2007). Nitrogen fixing domain showed high frequency (18\%) among the genera Mastigocladus, Nostoc, Anabaena etc. (LAKSHMI et al. 2009).

Mastigocladus laminosus was indentified from other hot springs: Kaziczene, Ravno Pole, Zheleznitza, in Sofia basin, Strelcza near, Gradeshnitza, in the Sandanski basin (LUKAVSKÝ et al., not published). Mastigocladus laminosus was found in 2000-2001 at Rupite, near Sandanski also (ZIDAROva 2001). Vodenicharov et al. (1971) did not list Mastigocladus laminosus, but they mentioned Hapalosiphon fontinalis in the thermal waters of the Pirin and the Rila ranges. Maybe Mastigocladus was not recognised, since there are no drawings of the species. 


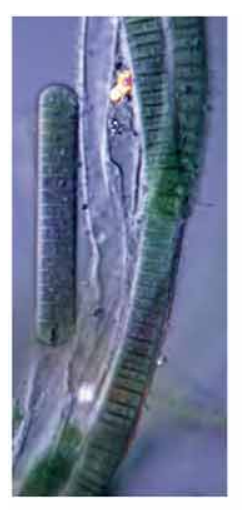

1
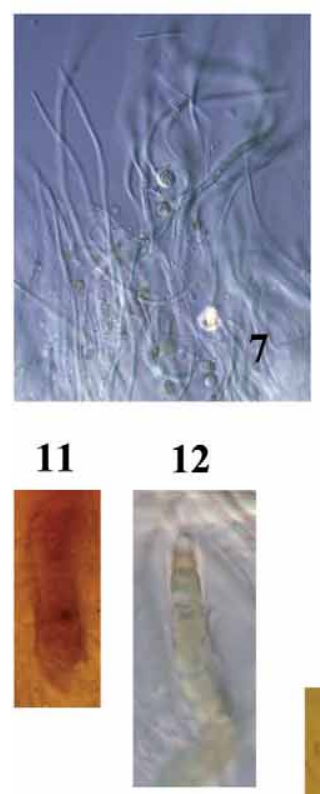

13

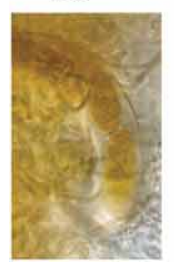

1

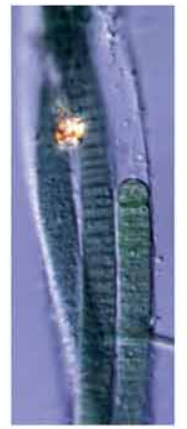

2

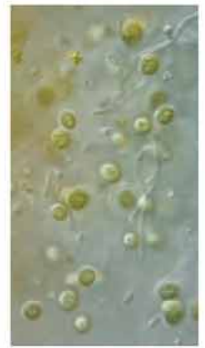

8
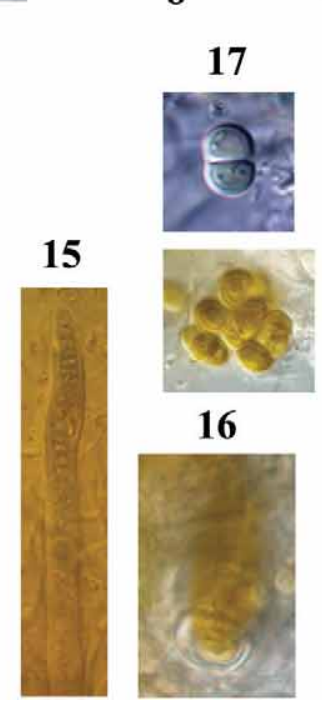
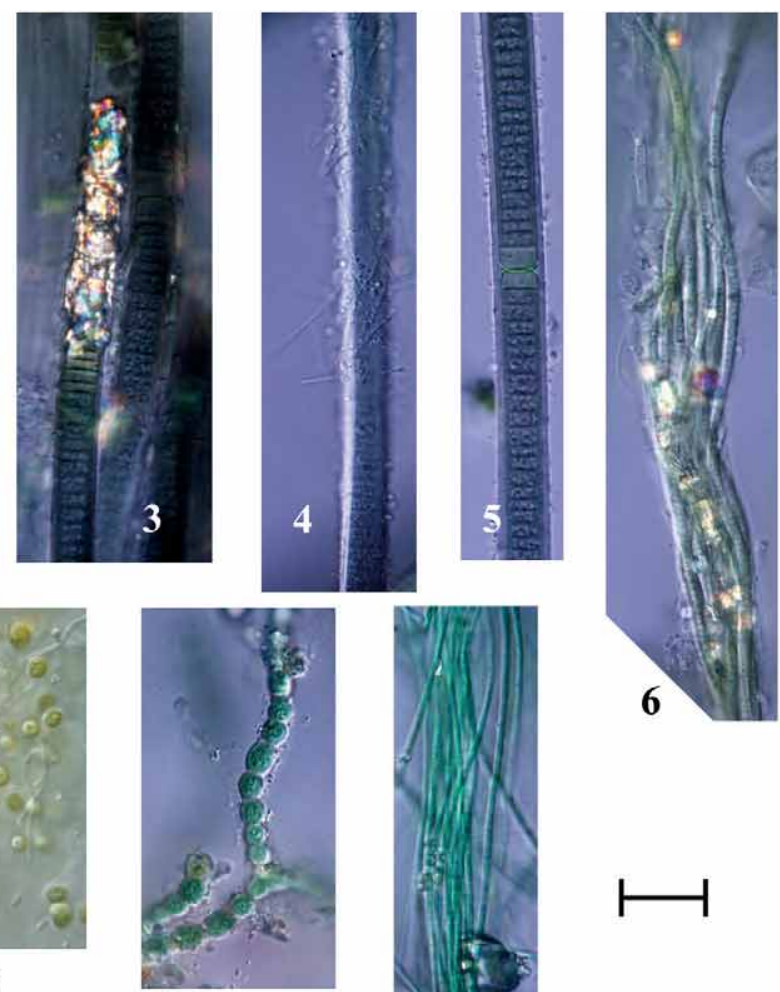

9

\section{8}
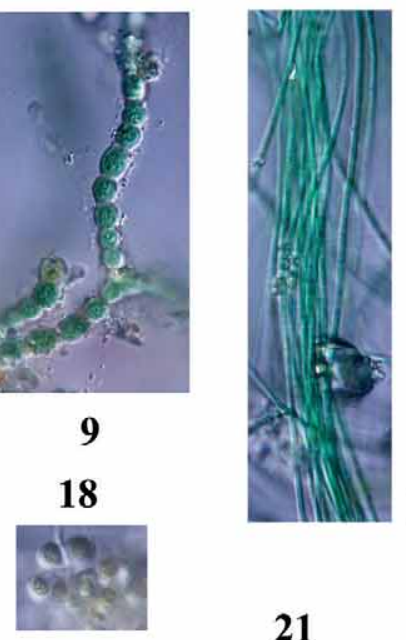

10

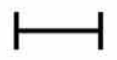

\section{1}

\section{9}

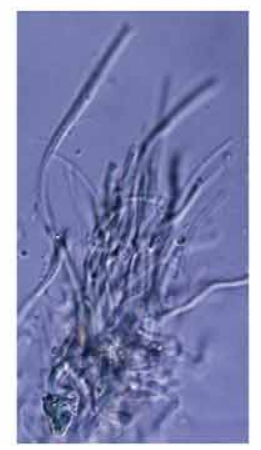

22

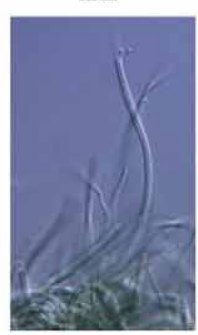

Plate 5. Microscopy picture of mat, on concrete wall, from different places in Pancharevo, leg. December 16, 2008, see Plate 4, Fig. 2, a - 1-6, b - 7-8, c - 11-21. 1-5 - Lyngbya thermalis, 6 Symploca thermalis, (a, $46^{\circ} \mathrm{C}$, blue mat). 7 - Symploca thermalis. 8 - Gloeocapsa gelatinosa 9-Mastigocladus laminosus (b, $21^{\circ} \mathrm{C}$, green mat). 10 - Symploca thermalis $\left(21^{\circ} \mathrm{C}\right.$, green mat in another place). 11-16 - Calothrix thermalis, 17-20 -Gloeocapsa gelatinosa. 21-22 Symploca thermalis $\left(\mathrm{c}, 16^{\circ} \mathrm{C}\right.$, red mat). Bar denotes $10 \mu \mathrm{m}$. 
Sulphur concentration: Mastigocladus proved to be sensitive to soluble sulphur. Mastigocladus laminosus f. typica tolerates max. of 5-7 $\mathrm{mg} \mathrm{L}^{-1}$. Mastigocladus laminosus f. nostocoides was sensitive to concentrations of $\mathrm{S}<0.15-0.25 \mathrm{mg} \mathrm{L}^{-1}$ (CASTENHOLZ 1976). The content of total $\mathrm{S}$ was $12.9 \mathrm{mg} \mathrm{L}^{-1}$ according to PENTCHEVA et al. (1997). The other conditions in Pancharevo, temperature of $49.5^{\circ} \mathrm{C}$ and $\mathrm{pH} 7.3$, agree with limits cited in the literature.

Biotechnology prospects: $M$. laminosus has become a »hot model organism studied in laboratories, also with a potential for biotechnological applications e.g. gliding of its hormogonia through agar (ROBINSON et al. 2007), and production of capsular polysaccharides and their anti-cancer activity (GLOAGUEN et al. 1999, 2007). It is also interesting that its ferredoxin activity was optimal at $65^{\circ} \mathrm{C}$ (FISH et al. 2005), but the alga was shown to grow as a branched form at $<53{ }^{\circ} \mathrm{C}$, and unbranched form in $60^{\circ} \mathrm{C}$ (CASTENHOLZ 1972). $M$. laminosus has been demonstrated as a pioneer species for a laboratory model of cyanobacterial mat (BRYANSKAYA et al. 2008).

The problem of Mastigocladus laminosus obviously needs further observation in the field, but also followed with cultivation experiments and sequencing in the lab. The strain Lukavsky 2008/33 is deposited in the culture collection CCALA Třeboň.

\section{Spatial variability of mat}

The cyanobacterial mat changed its composition and colour with respect to its position with respect to the source of hot water (Plate 1, Fig. 4), i.e. the intensities of splashing and the resulting temperatures.

Mastigocladus laminosus dominated at the temperature of $48.5^{\circ} \mathrm{C}$, e.g. at the mouths of the pipes (Plate 4, Fig. 1). A deep blue-green growth, washed direct with water of $43{ }^{\circ} \mathrm{C}$ (Plate 4, Fig. 3-a,) was colonized with Lyngbya thermalis. A green mat, splashed only with a small amount of water of $21{ }^{\circ} \mathrm{C}$ (Plate 4, Fig.3-b), was dominated by Symploca thermalis and Gloeocapsa gelatinosa. A green mat in another place, splashed intensively with water, even under an identical temperature $21^{\circ} \mathrm{C}$, was colonized with M. laminosus and Symploca thermalis (Plate 5, Fig.10). A red growth (Plate 4, Fig. 3-c), with only a small increase over air temperature, $16^{\circ} \mathrm{C}$, dry, wetted only by vapour, was colonized with Phormidium molle, Calothrix thermalis, Gloeocapsa gelatinosa and Symploca thermalis. The last species showed a greater spectrum of adaptability to temperature and conditions. Bblack spots on the wall, near the outlets of hot water of $22^{\circ} \mathrm{C}$ (Plate 1, Fig. 4) were dominated by Lyngbya thermalis and Phormidesmis molle. The data concur with CASTENHOLz $(1969,1973)$, who stressed that dramatic changes of temperature occurred along the gradient from the mouth of the spring, with concomitant changes in species composition.

\section{Species richness}

Seven species belonging to five genera of Cyanobacteria, from a spring at Pancharevo is comparable with the published literature, e.g. 13 springs studied in central Africa where MPAWENAYO et al. (2005) determined a total of 92 taxa of algae including Cyanobacteria and 80 taxa were Bacillariophyceae. In 14 springs in Sklené Teplice, Slovakia, 29 genera and 30 species of Cyanobacteria were identified (HINDÁK and HiNDÁKOVÁ 2007). In three maturing concrete basins of Pieš any Spa, Slovakia (temperature 45-60 ${ }^{\circ} \mathrm{C}$ ), 19 genera with 15 species were identified (HINDÁK and HINDÁKOVÁ 2006). 


\section{Precipitation of limestone}

The Pancharevo spring is of a dolomite and limestone type, and it has over $3 \mathrm{~g} \mathrm{~L}^{-1}$ of $\mathrm{CO}_{3}{ }^{2-}$ and $\mathrm{CO}_{3}{ }^{-}$. Grains of travertine precipitated on sheaths of Phormidium papyraceum (Plate 2, Figs. 27, 28, 30), Phormidium mollum (Plate 3, Figs. 6, 14), and also in clusters of filaments of Symploca thermalis (Plate 2, Figs.4, 6, 7), Mastigocladus laminosus (Plate 3, Fig. 13) and Lynbya thermalis (Plate 5, Fig.3). This precipitation is caused by photosynthesis, which intensively consumes $\mathrm{CO}_{2}$, and also by cooling the water outside the spring (COHN 1862, Ferrari et al. 2002). Because travertine is a quite stable and environment-friendly substance, these species are potential candidates for capturing, mitigation and as a sink for $\mathrm{CO}_{2}$ from point sources of the gas (HsueH et al. 2007, ONO and CuELLO 2007, OBST et al. 2009). The advantages of thermophilic species are their capacity to grow in both a high temperature, and a high concentration of $\mathrm{CO}_{2}$, which are common in point sources of $\mathrm{CO}_{2}$. Future experiments are necessary to evaluate the potency of such cultures.

\section{Conservation of the locality}

Pancharevo is very attractive locality, having a small spa and public swimming pool with thermal water, and with marginal capital investment should result in a great economic exploitation for the locality. The outlet of hot water is still semi-natural, exposed to light and it is a suitable place for growth of thermophilic cyanobacteria. It would be important to protect this important ecological habitat and to conserve this refugium of interesting and valuable genotypes. Four new species were recorded for Bulgaria. It is essential to set up some protective measures to prevent the deterioration of the site in the same way as at Karlovy Vary, Czech Rep., where »almost all springs were closed and changed into a hot water supply system, and remain completely without phototrophic microvegetation «, in spite of the fact that it is classic algological locality (KAŠTOVSKÝ 2001).

\section{Acknowledgements}

We thank grant No. 1M 0571 of the Ministry of Education of the Czech Republic, AVO Z60050516 of Acad. Sci. the Czech Republic, grant »New microalgal strains - potential producers of economical and medical important products «, DO 02-299/08.12.2008 funded by the National Science Fund, and »Study of cyanoprokaryotes and algae from extreme habitats « of Bulgarian Academy of Sciences for financial support; R.W. Castenholz, and F. Hindák for valuable comments; H. Brabcová, and V. Titlová for technical assistance. L. E. Shubert kindly edited the English.

\section{References}

AdHIKARY, S. P., 2006: Blue green algae, survival strategies in diverse environmemnt. Pointer Publishers, Jaipur (Raj) India.

AnAgNostidis, K., 1961: Untersuchungen über die Cyanophyceen einiger Thermen in Greichland. PhD Thesis, University of Thessaloniki.

Anagnostidis, K., KomÁreK, J., 1990: Modern approach to the classification system of Cyanopytes, 5, Stigonematales. Algological Studies 59, 1-73. 
Becher, P. G., Bumann, H. I., Gademann, K., 2009: The cyanobacterial alkaloid nostocarboline: an inhibitor of acetylcholinesterase and trypsin. Journal of Applied Phycology 21, 103-110.

BHANDARI, R., SHARMA, P. K., 2006: High-light-induced changes on photosynthesis, pigments, sugars, lipids and antioxidant enzymes in freshwater (Nostoc spongiaeforme) and marine (Phormidium corium) cyanobacteria. Photochemistry and Photobiology 82, 702-710.

Bhandari, R., Sharma, P. K., 2007: Effect of UV-B and high visual radiation on photosynthesis in freshwater (Nostoc spongiaeforme) and marine (Phormidium corium) cyanobacteria. Indian Journal of Biochemistry and Biophysics 44, 231-239.

Bidigare, R. R., Ondrusek, M. E., Iturriaga, R., Harvey, H. R., Hoham, R. W., Macko, S. A., 1993: Evidence for a photoprotective function for secondary carotenoids of snow algae. Journal of Phycology 29, 427-434.

Bryanskaya, A. V., Orleanskit, V. K., Dagurova, O. P., 2008: A laboratory model of the cyanobacterial mat from Kotel'nikovskii hot spring (Baikal region). Microbiology 77, 490-496.

Castenholz, R. W., 1969: Thermophilic blue-green algae and the thermal environment. Bacteriological Reviews 33, 476-504.

Castenholz, R. W., 1972: The occurrence of the thermophilic blue-green alga, Mastigocladus laminosus, on Surtsey in 1970. Surtsey Progress Report 6, 14-19.

Castenholz, R. W., 1973: The possible photosynthetic use of sulfide by the filamentous phototrophic bacteria of hot springs. Limnology and Oceanography 18, 863-876.

Castenholz, R. W., 1976: The effect of sulfide on the bluegreen algae of hot springs. I. New Zealand and Iceland. Journal of Phycology 12, 54-68.

CoHn, F., 1862: Über die Algen des Karlsbader Sprudels, mit Rücksicht auf die Bildung des Sprudelsinters. Abhandlungen der Schleisichen Gesselschaft und Vaterländische Kultur 5, 37-55.

ERtugrul, S., BAKIR, M., DonMEz, G., 2008: Treatment of dye-rich wastewater by an immobilized thermophilic cyanobacterial strain: Phormidium sp. Ecological Engineering $32,244-248$.

FERrari, S. G., ItAliano, M. C., Silva, H. J., 2002: Effect of a cyanobacterial community on calcium carbonate precipitation in Puente del Inca (Mendoza, Argentina). Acta Botanica Croatica 61, 1-9.

Finsinger, K. Scholz, I., Serrano, A., Morales, S., Uribe-Lorio, L., Mora, M., SitTenfeld, A., WeCKesser, J. Hess, W. R., 2008: Characterization of true-branching cyanobacteria from geothermal sites and hot springs of Costa Rica. Evinronmental Microbiology 10, 460-473.

FISH, S. A., CoDD, G. A., 2004: Bioactive compound production by thermophilic and thermotolerant cyanobacteria (blue-green algae). World Journal of Microbiology and Biotechnology 10, 338-341.

Fish, A., Danieli, T., OHAD, I., Nechushtai, R., LiVnah, O., 2005: Structural basis for the thermostability of ferredoxin from cyanobacterium Mastigocladus laminosus. Journal of Molecular Biology 350, 599-608. 
Fournadzhieva, S., Bojadgieva, K., Fytikas, M., Popovski, K., 2002: A conception of a geothermal application in common microalgal development in Balkan countries. In: Popovski, K., Fytikas, M. (eds.) Proceedings of the International course on district heating, agricultural and agro-industrial uses of geothermal energy. Aristotle University Tessaloniki, Tessaloniky, 152-159.

Furnadzhieva, S., Lukavský, J., Pilarski, P., 2006: Algae and cyanobacteria of hot springs of Bulgaria. Proceedings of abstracts 4 Balkan Botanical Congress, Sofia, Bulgaria, 184.

Gloaguen, V., Morvan, H., Hoffmann, L., Plancke, Y., Wieruszelski, J. M., LipPens, G., STRECKER, G., 1999: Capsular polysaccharides produced by the thermophilic cyanobacterium Mastigocladus laminosus. Structural study of an undecasaccharide obtained by lithium degradation. European Journal of Biochemistry/FEBS 266, 762-770.

Gloaguen, V., Morvan, H., Hoffmann, L., Saionte, C., Kraemer, M., Krausz, P., 2007: Bioactive capsular polysaccharide from the thermophilic Cyanophyte/Cyanobacterium Mastigocladus laminosus-cytotoxic properties. Planta Medica 73, 1402-1406.

GolD, T., 1992: The deep, hot biosphere. Proceedings of the National Academy of Sciences 89, 6045-6049.

GoLD, T., 1999: The deep hot biosphere: the myth of fossil fuels. 235 pp. Springer Verlag, N.Y.

Hayashi, N. R., Peerapornpisal, Y., Nishimura, H., Ishi, M., Igarashi, Y., Kodama, T., 1994: Isolation and cultivation of thermophilic Cyanobacteria from hot springs of Northern Thailand. Journal of Fermentation and Bioengineering 78, 179-181.

HINDÁK, F., 2008: On Chlorogloeopsis fritschii (Cyanophyta/Cyanobacteria) from thermal springs in Slovakia and from saline lake in Tunisia. Algological Studies 126, 47-64.

Hindák, F., HindákovÁ, A., 2006: Cyanobacteria and algae of thermals waters at the Pieš any Spa (Western Slovakia). Bulletin Slovenskej Botanickej Spoločnosti 28, 21-30.

HindÁk, F., HindÁKovÁ, A., 2007: Cyanobacteria and diatoms of thermal waters at Sklené Teplice (Central Slovakia). Bulletin Slovenskej Botanickej Spoločnosti 29, 10-16.

Hsueh, H. T., CHu, H., Yu, S. T., 2007: A batch study on the bio-fixation of carbon dioxide in the absorbed solution from a chemical wet scrubber by hot spring and marine algae. Chemosphere 66, 878-886.

JAVOR, B. J., 1999: Cancer drugs from thermophilic cyanobacteria. Grant National Cancer Institute. http://www.researchcrossroads.org/index.php?view=article\&id=50\%3Agrant-details\&option=com_content\&Itemid=37\&grant_id=2626930. Access: 27.11.2009.

Izagiurre, I., Allende, L., Tell, G., 2006: Algal communities of a geothermally heated lagoon on Deception Island (South Shetlands Islands). Polar Biology 29, 364-371.

KAŠTOVSKÝ, J. 2001: The photorophic microvegetation of seminatural thermal springs in Karlovy Vary, Czech Republic. PhD Thesis, University of South Bohemia, Č. Budìjovice. http://botanika.bf.jcu.cz/thesis/pdf/KastovskyJ_Mgr97.pdf.

KaŠTovskÝ, J., Johansen, J. R., 2008: Mastigocladus laminosus (Stigonematales, Cyanobacteria): phylogenetic relationship of strains from thermal springs to soil-inhabiting genera of the order and taxonomic implications for the genus. Phycologia 47, 307-320. 
KAŠTOVskÝ, J., KOMÁREK, J., 2001: Phototrophic microvegetation of thermal springs in Karlovy Vary, Czech Republic. In: Ester, J., SeckBAch, J., Vincent, W. F., Lhotský, O. (eds.), Algae and extreme environments. Nova Hedwigia, Suppl 123, 107-119.

KomÁReK, J., AnAgnostidis, K., 1998: Cyanoprokaryota, 1: Chrooococcales. In: EtTL, H., Partner, G., Heynig, H., Mollenhauer, D., (eds), Süsswasserflora Mitteleuropa 19/1, 1-548. G. Fischer, Jena.

KomÁReK, J., AnAgnostidis, K., 2005: Cyanoprocaryota, 2/2, Oscillatoriales. In: EtTL, H., Partner, G., Heynig, H., Mollenhauer, D. (eds.), Süsswasserflora Mitteleuropa 19/2, 1-758. Elsevier, München.

Komárek, J., Kaštovský, J., Ventura, S., Turicchia, S., Šmarda, J., 2009: The cyanobacterial genus Phormidesmis. Algological Studies 129, 41-49.

KomÁREK, J., HAUER, T. 2010: CyanoDB.cz - On-line database of cyanobacterial genera. Word-wide electronic publication, Univ. of South Bohemia and Inst. of Botany AS CR, http://www.cyanodb.cz. Access: March 12, 2010.

Lakshmi, P. T. V., Maheswari, S. U., Annamalai, A. 2009: Structure-function annotation and phylogenetic strategy of nifH domain of a cyanobacterium-Chlorogloeopsis sp. Indian Journal of Biotechnology 8, 46-52.

LEWIN, R. A. 2006: Black algae. Journal of Applied Phycology 18, 699-702.

Maslova, I. P., Mouradyan, E. A., Lapina, S. S., Klyachko-Gurvich, G. L., Los, D. A. 2004: Lipid fatty acid composition and thermophicity of Cyanobacteria. Russian Journal of Plant Physiology 51, 353-360.

Miller, S. R., Purugganan, M. D., Curtis, S. E., 2006: Molecular population genetics and phenotypic diversification of two populations of the thermophilic cyanobacterium Mastigocladus laminosus. Applied and Environmental Microbiology 72, 2793-2800.

Miller, S. R., Castenholz, R. W., Pedersen, D. 2007: Phylogeography of the thermophilic cyanobacterium Mastigocladus laminosus. Applied and Environmental Microbiology 73, 4751-4759.

Miller, S. R., Williams, C., Strong, A. L., Carvey, D. 2009: Ecological specialization in a spatially structured population of the thermophilic cyanobacterium Mastigocladus laminosus. Applied and Environmental Microbiology 75, 729-734.

Mitsui, A., 1987: Photobiological production of hydrogen from water and waste. Proceedings of the hydrogen photo-production workshop. Hawaii Natural Energy Institute University of Hawaii at Manoa, Honolulu, Hawaii, 1-51.

MiYake, M., ERATA, M. AsadA, Y. 1996: A thermphilic cyanobacterium, Synechococcus sp. MA19, capable of accumulating poly- $\alpha$-hydroxybutylrate. Journal of Fermentation and Bioengeneering 82, 512-514.

Mohamed, Z. A., 2008: Toxic cyanobacteria and cyanotoxins in public hot springs in Saudi Arabia. Toxicon 51, 17-27.

Mpawenayo, B., Cocquit, C., Nindorea, A., 2005: Diatoms (Bacillariophyta) and other algae from the hot springs of Burundi (Central Africa) in relation with the physical and chemical characteristics of the water. Belgian Journal of Botany 138, 152-164.

Obst, M., Dynes, J. J., Lawrence, J. R., Swerhone, G. D. W., Benzerara, K., KarunaKaran, C., KaZnatcheev, K., TyliszczaK, T., Hitschcock, A. P. 2009: Precipitation of 
amorphous $\mathrm{CaCO}_{3}$ (aragonit-like) by cyanobacteria: A STXM study of the influence of EPS on nucleation process. Geochimica et Cosmochimica Acta 73, 4180-4198.

OnO, E., Cuello, J. L., 2007: Carbon dioxide mitigation using thermophilic cyanobacteria. Biosystems Engineering 96, 129-134.

PALIK, P., 1949: Beitrag zur Kenntnis der Algenvegetation der Balintquelle des Bades Felixfürdö. Acta Biologica Hungarica 1, 40-55.

Pentcheva, E. N., Van't dack, L., Veldeman, E., Hristov, V., Gijbels, R., 1997: Hydrochemical characteristics of geothermal systems in South Bulgaria. Geological Institute, University of Antwerpen, Antwerpen.

Plescia, J. B., Johnson, J. R. \& Ferris, M., 2001: Visible-near infrared spectroscopy of hyperthermophile organisms, Yellowstone National Park. Proceedings of Abstracts General Meeting of the NASA Astrobiology Institute, Carnegie Institution of Washington, Washington, DC, 129-130.

Raungsomboon, S., Chidthaisong, A., Bunnag, B., Inthorn, D., Harvey, N. W., 2006: Production, composition and $\mathrm{Pb}^{2+}$ adsorption characteristics of capsular polysaccharides extracted from a cyanobacterium Gloeocapsa gelatinosa. Water Research 40, 3759-3766.

Robinson, W. B., Mealor, A. E., Stevens, S. E., Ospeck, M., 2007: Measuring the force production of the hormogonia of Mastigocladus laminosus. Biophysical Journal 93, 699-703.

Singh, K. R., TiwARI, G. L. 2007: Physiological characterization of certain strains of Stigonematales. National Academy of Sciences, Letters-India 30, 269-272.

StARMACH, K. 1966: Cyanophyta-sinice, Glaukophyta-glaukofity. In: Starmach, K. (ed.), Flora slodkowodna Polski 2, 1-806. Panstwowe Wydawnictwo Naukowe, Warszawa.

Stoyneva, M., 2003: Survey on green algae of Bulgarian thermal springs. Biologia, Bratislava, 58, 563-574.

Stoyneva, M., GÄrTnER, G., 2004: Taxonomic and ecological notes to the list of green algal species from Bulgarian thermomineral waters. Berichte des Naturwissenschaftlich-Medizinischen Vereins in Innsbruck 91, 67-89.

Teneva, I., Dzhambazov, B., Koleva, L., Mladenov, R., Schirmer, K., 2005: Toxic potential of five freshwater Phormidium species (Cyanoprokaryota). Toxicon 45, 711-725.

Turicchia, S., Venturo, S., KomÁrkovÁ, J., KomÁreK, J., 2009: Taxonomic evaluation of the cyanobacteria microflora from alkaline marsches of northern Belize. 2. Diversity of oscillatorialean genera. Nowa Hedvigia 89, 165-200.

Udomluk, S., Castenholz, R. W., Anuntalabhochai, S., Peerapornpisal, Y., 2006: Gentic diversity of Mastigocladus in Ranong hot spring, southern part of Thailand. Chiang Mai Journal of Science 33, 363-370.

Vodenicharov, D., Draganov, S., Temniskova, D., 1971: Flora of Bulgaria - thermophilic algae [In Bulgarian]. Narodna prosveta, Sofia.

Weismann, J. C., Radway, J. C., Wilde, E. W., Benemann, J. R., 1998: Growth and production of thermophilic cyanobacteria in a simulated mitigation process. Biosource Technology 65, 87-95. 
LukavskÝ J., Furnadzhieva S., Pilarski P.

Wilmotte, A., Van der Auwera, G., De Wachter, R., 1993: Structure of the 16 S ribosomal RNA of the thermophilic cyanobacterium Chlorogloeopsis HTF ('Mastigocladus laminosus HTF') strain PCC7518, and phylogenetic analysis. FEBS Letters 317, 96-100.

ZIDAROVA, R. P., 2001: Observation of algae in thermal spring »Rupite«[In Bulgarian]. Diploma Thesis, University of St. Kliment Ohridski, Sofia. 